\title{
DETERMINANTS OF Irvingia SPECIES KERNEL (Ogbono) SUPPLY AND DEMAND IN DELTA STATE, NIGERIA
}

\author{
O. Ojogho and R. A. Egware
}

\begin{abstract}
The study examined the determinants of Irvingia species (ogbono) in Aniocha North and South Local Government Areas of Delta State of Nigeria. Primary data were mainly used in the study. The data were collected using two sets of well-structured questionnaire containing items on the supply information for producer and demand information respectively on ogbono in the study area. A two-stage sampling technique was used to sample respondents in the area. A total of sixty (60) copies of the producer-set and one hundred and twenty (120) copies of the consumer-set of questionnaire respectively were valid for analysis for the study. Data collected were subjected to inferential statistics using multivariate analysis, involving correlation analysis, Principal Component Analysis (PGA), and the standardized beta-weight multiple regression analysis. The results showed that, among the determinants of the supply of ogbono in the study area, the initial supply price, mid-season supply price and the end-season price were statistically significant at 5\% level of significance. Among the determinants of irvingia kernel (ogbono) demand, the initial demand price, mid-season demand price, end-of-season demand price, price of substitute commodity were statistically significant. Therefore, institutional framework that will guarantee stable price of ogbono will ultimately translate to improved economic base and sustained livelihoods of the people of Aniocha in Delta State, Nigeria.
\end{abstract}

Keyword: Irvingia, PCA, eigen-value, eigen-vector, beta weight, ogbono.

\section{INTRODUCTION}

Irvingia species are forest trees that are commonly found in the farm lands of the Aniocha zone of Delta state. Besides being valued for their wood and edible nuts, it ranks as the most important species for food and commercial value in Cameroun and other West African countries like Nigeria (Mbosso, 1999), while the kernels (ogbono) are used as thickening agent in traditional soups and stews in West and Central Africa (Leaky, et. al., 2003). They are also a source of oil for making soap, and for medicinal purposes (Abbiw, 1990). They, thus, provide opportunities for achieving the goal of sustenance among consumers, and income diversification as a strategy to minimizing the risks associated with conventional practices among farmers (Ayuk, et.al., 1999). Falconer (1990) put the quantity of Irvingia kernel marketed in Nigeria annually at over 78, 000 tonnes. Processed kernels (ogbono) are traded within Nigeria and between countries in West and Central Africa, and to Europe and the United State (Lapido and Boland, 1994). Though, many households in the study area embark on the establishment of Irvingia agro-forestry and consumption of its products to sustain livelihood and secure food in order to offset the impact of shocks on consumption (Blundell and Preston, 1999; Dercon and Krishnan, 2000), the production of the crop and consumption of its products are not devoid of barriers. In explaining the 
determinants of the supply and demand for Irvingia, one is tempted to ask: what are the determinants of irvingia kernel, and are the contribution of each to the regression equation explaining the effect of these factors on the production and consumption of the crop, ceteris paribus? In answering these questions, a main goal of this study will be the explicit quantification of the relative importance of each regressor for the response.

The study therefore, examined some determinants of the supply and demand of Irvingia kernel (ogbono)in the study area, derived the functional relationship among the determinants and the quantity supplied and demanded respectively, and determined the relative importance of each determinant.

\section{Theoretical Framework}

Across behavioral science disciplines like Agricultural economics that rely on observational studies, multiple linear regression is a standard statistical technique in a researcher's toolbox. As an extension of simple linear regression, multiple linear regression provide answers to questions that consider the role(s) that multiple independent variables play in accounting for variance in a single dependent variable. Assigning shares of "relative importance" to each of a set of regressors is one of the key goals of researchers applying linear regression, particularly in sciences that work with observational data (Johnson and Lebreton, 2004; Fickel, 2001; Firth, 1998; Kruskal and Majors, 1989). "Relative importance" refers to the quantification of an individual regressor's contribution to a multiple regression model. Assessment of relative importance in linear models is simple, as long as all regressors are uncorrelated: Each regressor's contribution is just the $\mathrm{R}^{2}$-value from univariate regression, and all univariate $\mathrm{R}^{2}$-values add up to the full model $\mathrm{R}^{2}$-value. If all regressors are uncorrelated, there is a simple and unique answer to the relative importance question.
However, it is the very nature of observational data that regressors are typically correlated. In this case, assignment of relative importance becomes a challenging task, for which the standard output from linear regression models is not particularly well suited. Nevertheless, various methods have been proposed in literature (Feldman, 2005; Gromping, 2006; Johnson and Lebreton, 2004; Fox, 2002; Walsh and Mac Nally, 2005; Firth, 2006; Nimon, et. al, 2010; Zientek, et. al, 2008; Hoyt, et. al, 2006; Pratt, 1987; Afifi, et.al, 2012; van Belle, et. al, 2004; Rabe-Hesketh and Everitt, 2007; Rencher and Christensen, 2012; Jackson, 2003; and Jolliffe, 2002)

\section{METHODS AND METERIALS}

The study was carried out in Aniocha North and South Local Government Areas of Delta State of Nigeria with headquarters in IseleUku and Ogwashi-Uku respectively. Together, the two Local Government Areas have an estimated population of 256403 , a total land area of 1346 square Kilometres with a tropical climate of two season, viz, the raining season and the dry season, and the tropical rainforest belt vegetation. Besides farming, most of the indigenes are traders who consume variety of food items, and irvingia (ogbono) an important ingredient in their soup dishes while the oil from it is used in soap production for the market. Primary data were mainly used in the study. The data were collected using two sets of well-structured questionnaire containing items on the supply information for producer and demand information respectively on ogbono in the study area. A two-stage sampling technique was used to sample respondents in the area. The first stage involved a purposive sampling of four towns because of their large market for the product. The four towns were IseleUku, Otulu, Ubulu-Uku and Ogwashi-Uku. The second stage involved a random sampling technique using the random number table to select both producers and consumers in the study area. A total of seventy (70) copies of the 
producer-set of questionnaire and one hundred and thirty-five (135) copies of the consumerset of questionnaire were administered, but only sixty (60) copies of the producer-set and one hundred and twenty (120) copies of the consumer-set of questionnaire respectively were valid for analysis for the study. These represent response rate of $85.71 \%$ and $88.89 \%$ respectively. Data collected were subjected to inferential statistics using multivariate analysis. The supply equation, in the variable level forms, was given as:

$y_{s}=\alpha_{0}+\alpha_{1} x_{1}+\alpha_{2} x_{2}+\alpha_{3} x_{3}+\alpha_{4} x_{4}+\alpha_{5} x_{5}+\alpha_{6} x_{6}+\alpha_{7} x_{7}$ [1]

where $x_{1}, x_{2}, x_{3}, x_{4}, x_{5}, x_{6}$ and $x_{7}$ are respectively supply price of ogbono, mid-season supply price, end-season price, distance between production centre and market, shelf-life of seeds, price of substitute and price of complementary commodities.

Similarly, the demand equation, in the variable level forms, was given as:

$y_{d}=\beta_{0}+\beta_{1} z_{1}+\beta_{2} z_{2}+\beta_{3} z_{3}+\beta_{4} z_{4}+\beta_{5} z_{5}+\beta_{6} z_{6}+\beta_{7} z_{7}+\beta_{8} z_{8}+\beta_{9} z_{9}+\beta_{10} z_{10}$

\section{[2]}

Where $z_{1}, z_{2}, z_{3}, z_{4}, z_{5}, z_{6}, z_{7}, z_{8}, z_{9}$, and $z_{10}$ are respectively demand price of ogbono, mid-season demand price, end-season price, distance between market and consumption centre, quality of seeds, price of substitute and price of complementary commodities, taste, taboo and income.

To estimate the coefficients of both the supply and demand equations above with a view to establishing the determinants of Irvingia demand and supply, all suspected variable determinants were first used to estimate their coefficient in the standardized form, principal component analysis of the variables was then conducted to compensate for the sample size. Only variables with significant loading were then used to estimate their standardized (i.e., converted to z-scores) beta-coefficients. Researches show that beta weights are heavily relied on to assess variable importance (Courvilleand Thompson, 2001; Nimon, Gavrilova, and Roberts, 2010; Zientek, Carpraro, andCapraro, 2008; Thomas, Zhu, and Decady, 2007).

\section{RESULTS AND DISCUSSION}

\section{Determinants of Irvingia kernel (ogbono) Supply}

Table 01 summarizes the correlation matrix, eigen-values, showing the values, the forward difference in the eigen-values, the proportion of total explained variance, the cumulative proportion, and eigen-vectors loadings for irvingia kernel supply in the study area. The Table shows that most of the variables were negatively correlated with the price of irvingia. The results show that the correlation was highest, in absolute terms, between the mid-price supply of irvingia and initial supply price $(-0.9067)$, followed by that between the price of complement of the commodity and shelf-life (0.4999), then that between midseason supply price and the price of substitute $(-0.3639)$ and least between the price of complement and the mid-season supply price $(-0.0041)$. This implies that any increase in the initial supply price of the commodity would lead to a corresponding increase in the midseason supply price of irvingia

The results also show that the sum of the scaled variances for the ten variables is equal to seven (7).The first principal component (PC1) has variance (eigen-value) 1.6675 and accounts for $23.8 \%$ of the total variance in the supply for Ogbono kernel in the study area. The second, third, fourth and fifth principal components have variance of $1.5026,1.1856$, 0.8644 , and 0.7625 respectively with each accounting for $21.5 \%, 16.9 \%, 12.4 \%$ and $10.9 \%$ respectively of the variance in the supply of Ogbono kernel in the study area. Together, the first-five principal components represent $85.5 \%$ of the total variability. This implies that most of the data structure can 
be captured in five underlying dimensions. The remaining principal components (PC1), price of substitute and price of complement, account for a very small proportion of the variability and are probably unimportant. The fifth principal component, with one negative and six positive loadings for the determinants of Ogbono kernel supply, represents an overall initial supply price $(0.120)$, end-ofseason supply price (0.513), shelf-life of seed $(0.154)$ and distance between market and consumption center (0.683) since the coefficients of these terms have the same sign and are not close to zero. It might reasonably be interpreted as a general supply function for Ogbono kernel in the study area. However, the first principal component, with a variance of 1.668 and accounting for the highest (23.8\%) of the total variance in the supply of Ogbono kernel, seems to represent a supply specific component.

Table 01: Principal Component Analysis of Irvingia Kernel (Ogbono) Supply in the Study Area

\begin{tabular}{|c|c|c|c|c|c|c|c|}
\hline \multicolumn{8}{|c|}{ Correlation Matrix } \\
\hline Variable & S-P & MSS-P & ESS-P & SLIFE & MCD & SUB-P & COM-P \\
\hline S-P & 1.0000 & & & & & & \\
\hline MSS-P & -0.9067 & 1.0000 & & & & & \\
\hline ESS-P & 0.0787 & 0.1290 & 1.0000 & & & & \\
\hline SLIFE & 0.0710 & -0.0288 & -0.1389 & 1.0000 & & & \\
\hline MCD & -0.1190 & 0.2039 & -0.0419 & -0.0042 & 1.0000 & & \\
\hline SUB-P & -0.1806 & -0.3639 & -0.0492 & -0.1070 & -0.1890 & 1.0000 & \\
\hline COM-P & 0.0530 & -0.0041 & -0.1908 & 0.4999 & 0.0447 & -0.1528 & 1.0000 \\
\hline \multicolumn{8}{|c|}{ Eigen-values: $($ sum $=07$, Average value $=1$} \\
\hline & S-P & MSS-P & ESS-P & SLIFE & $\mathrm{MCD}$ & SUB-P & COM-P \\
\hline Eigen-value & 1.6675 & 1.5026 & 1.1856 & 0.8644 & 0.7625 & 0.5256 & 0.4919 \\
\hline Difference & 0.165 & 0.317 & 0.321 & 0.102 & 0.237 & 0.034 & - \\
\hline Proportion & 0.238 & 0.215 & 0.169 & 0.124 & 0.109 & 0.075 & 0.070 \\
\hline Cum. Value & 1.6678 & 3.1701 & 4.3557 & 5.2200 & 5.9826 & 6.5081 & 7.0000 \\
\hline Cumulative & 0.238 & 0.453 & 0.622 & 0.746 & 0.855 & 0.930 & 1.000 \\
\hline \multicolumn{8}{|c|}{ Eigen-vectors (loadings): } \\
\hline & PC 1 & PC 2 & PC 3 & $\mathrm{PC} 4$ & PC 5 & PC 6 & PC 7 \\
\hline S-P & 0.1258 & -0.0712 & 0.7496 & -0.4783 & 0.1200 & 0.4023 & 0.1100 \\
\hline MSS-P & 0.1963 & 0.6129 & -0.0792 & 0.2550 & -0.4000 & 0.5794 & 0.1373 \\
\hline ESS-P & -0.2202 & 0.3307 & 0.4382 & 0.6032 & 0.5128 & -0.1408 & 0.0589 \\
\hline SLIFE & 0.5668 & -0.2849 & 0.0319 & 0.3253 & 0.1543 & 0.2296 & -0.6435 \\
\hline $\mathrm{MCD}$ & 0.2048 & 0.3926 & -0.4134 & -0.3945 & 0.6826 & 0.1064 & -0.0116 \\
\hline SUB-P & -0.4118 & -0.4630 & -0.2580 & 0.2002 & 0.2548 & 0.6304 & 0.2168 \\
\hline COM-P & 0.6036 & -0.2453 & -0.0362 & 0.2019 & 0.0895 & -0.1453 & 0.7101 \\
\hline
\end{tabular}

*S-P is initial supply price of ogbono, MSS-P is Mid-season supply price, ESS-P is End-of-season supply price, SLIFE is the shelf-life, MCD is distance between market and consumption centre, SUB-P is price of okra as substitute, COM-P is price of complementary commodity 
Determinants of irvingia kernel (ogbono) Supply in the Study Area

The results of the parameters estimate of the supply regression are presented in Table 02. The result shows an $\mathrm{R}^{2}$ of 0.977 and an adjusted $\mathrm{R}^{2}$ of 0.974 . The $\mathrm{R}^{2}$ value implies that $97.70 \%$ of the total variation in the quantity of ogbono supplied by producers in the study area is explained by the initial price, mid-season price, end-of-season price, distance between production centre and the market, price of substitutes and the price of complementary commodities in the area. The results also showed that, among the explanatory variable, the initial price and end-of-season price were significant at $1 \%$ level of significance while mid-season supply price and price of complementary commodities were significant at $5 \%$ and $10 \%$ respectively. Among these significant explanatory variables, the price of complementary commodities had a beta coefficient of 121.71, initial price had 1.07, and end-of-season price had 0.31 while the mid-season price coefficient was 0.28. These imply that,while a unit increase in the initial price of ogbono would be expected to increase the quantity supplied by producer in the area by 1.07 in standard deviation unit for a one standard-deviation, the same $\mathrm{N} 1.00$ increase in the end-of-season price and midseason price would be expected to increase the quantity supplied of ogbono by 0.31 and 0.28 respectively, ceteris paribus, in standard unit for a one standard-deviation. The 121.71 coefficient of the price of complementary commodities implied the difference, between when there are complementary commodities and when there are not, in the expected increase in the quantity of ogbono in standard deviation unit for a one standard-deviation, supplied by the producers in the study area.

\begin{tabular}{|c|c|c|c|}
\hline Variable & $\begin{array}{c}\text { Beta } \\
\text { Parameter }\end{array}$ & $\begin{array}{c}\text { Beta weight Coefficient Before Principal } \\
\text { Component Analysis }\end{array}$ & $\begin{array}{l}\text { Beta weight Coefficient After } \\
\text { Principal Component Analysis }\end{array}$ \\
\hline Constant & & $\begin{array}{c}870.44 * * * \\
(11.032)\end{array}$ & $\begin{array}{c}601.32 * * \\
(3.567)\end{array}$ \\
\hline S-P & & $\begin{array}{c}1.07 * * * \\
(-10.442)\end{array}$ & $\begin{array}{c}2.19 * * * \\
(5.31)\end{array}$ \\
\hline MSS-P & & $\begin{array}{l}0.28 * * \\
(5.376)\end{array}$ & $\begin{array}{l}0.93 * * \\
(2.77)\end{array}$ \\
\hline ESS-P & & $\begin{array}{l}0.31 * * * \\
(10.032)\end{array}$ & $\begin{array}{l}0.59 * * \\
(4.11)\end{array}$ \\
\hline SLIFE & & $\begin{array}{c}-5.15 \\
(-0.550)\end{array}$ & $\begin{array}{l}1.72 \\
(0.26)\end{array}$ \\
\hline MCD & & $\begin{array}{c}-19.34 \\
(-0.917)\end{array}$ & $\begin{array}{c}0.79 \\
(5.17)\end{array}$ \\
\hline SUB-P & & $\begin{array}{c}-27.36 \\
(-0.982)\end{array}$ & - \\
\hline COM-P & & $\begin{array}{l}121.71^{*} \\
(-2.848)\end{array}$ & - \\
\hline $\begin{array}{l}\text { Coefficient of deter- } \\
\text { mination }\end{array}$ & & 0.977 & 0.879 \\
\hline $\begin{array}{l}\text { Adjusted coefficient } \\
\text { of determination }\end{array}$ & Adj. & 0.974 & 0.868 \\
\hline
\end{tabular}

\footnotetext{
$*$ significant at $5 \%$ level, **significant at $10 \%$ level, *** significant at $1 \%$ level of significance
} 
The Table 02 also shows the estimates of the supply equation parameters after a principal component analysis. The results showed that the three statistically significant explanatory variables account for 0.879 , representing $87.9 \%$, of the total variation in the quantity of ogbono supplied by the producers while the others account for only 0.121 . The results showed that the initial supply price of irvinga, mid-season supply price and end-of-season price, with respective coefficient of 2.19 , 0.93 and 0.57 , are the major determinants of the supply of ogbono in the study area. These imply that $\mathrm{N} 1.00$ increase in the initial supply price of ogbono, mid-season supply price and end-of-season supply price would be expected to respectively increase the quantity supplied by producer in the area by $2.19,0.93$ and 0.59 , ceteris paribus, in standard unit for a one standard-deviation.

\section{Determinants of Irvingia kernel (ogbono) Demand}

The Table 03 summarizes the correlation matrix, eigen-values, showing the values, the forward difference in the eigen-values, the proportion of total variance explained and the cumulative proportion, and eigen-vectors loadings. The Table shows the co-movement of the irvingia demand determinants in the study area. The Table shows that most of the variables were positively correlated with the demand of irvingia. The results show that the correlation was highest, in absolute terms, between the price of complements of irvingia and income (-0.3989), followed by that between the price of substitutes of the commodity and the mid-season demand price $(-0.3987)$, then that between income and mid-season price $(-0.2847)$ and least between the price of substitute and taste of the commodity. However, the correlation coefficient between initial price of irvingia and the mid-season price, between initial price and end-of-season price, initial price and taste, and between initial price and quality of seed were respectively $0.0295,0.2145,0.0499$ and 0.0239 . This implies that any increase in the initial price of the commodity would lead to a corresponding increase in both the mid-season and end-of-season prices of irvingia while an improvement on the quality of seed and taste would increase the initial price.

The results also show that the sum of the scaled variances for the ten variables is equal to 10.The first principal component (PC1) has variance (eigen-value) 1.9263 and accounts for $18.3 \%$ of the total variance in the demand for Ogbono kernel in the study area. the second, third, fourth, fifth sixth, seventh and eighth principal components have variance of $1.5168,1.3502,1.056,0.954,0.945,0.7715$ and 0.6662 respectively with each accounting for $15.2 \%, 13.5 \%, 10.6 \%, 9.5 \%, 9.4 \%, 7.7 \%$ and $6.7 \%$ respectively of the variance in the demand for Ogbono kernel in the study area. Together, the first seven and the first eighth principal components represent $84.2 \%$ and $90.1 \%$, respectively, of the total variability. This implies that most of the data structure can be captured in seven or nine underlying dimensions. The remaining principal components (PC1), taste, taboo and income, account for a very small proportion of the variability and is probably unimportant. The first principal component, with four negative and six positive loadings for the determinants of Ogbono kernel demand, represents an overall initial demand price $(0.418)$, midseason demand price (0.366), end-of-season demand price $(0.304)$, quality of seed $(0.195)$ and taboo (0.395) since the coefficients of these terms have the same sign and are not close to zero. It might reasonably be interpreted as a general demand function for Ogbono kernel in the study area. However, the ninth principal component, with a variance of 0.4853 but accounting for only $4.9 \%$ of the total variance in the demand for Ogbono kernel, represents an overall mid-season demand price $(-0.447)$, distance between market and consumption centre $(-0.261)$, price of substitutes $(-0.684)$, 
price of complements $(-0.267)$ and taboo This component seems to represent a demand $(-0.412)$ since the coefficients of these terms specific component.

have the same sign and are not close to zero.

Table 03: Principal Component Analysis of Irvingia Kernel (Ogbono) Demand in the Study Area

\begin{tabular}{|c|c|c|c|c|c|c|c|c|c|c|}
\hline \multicolumn{11}{|c|}{ Correlation Matrix } \\
\hline Variable & D-P & MSD-P & ESD-P & INCOME & MCD & TASTE & SUB-P & QSEED & ТАВОО & COM-P \\
\hline D-P & 1.0000 & & & & & & & & & \\
\hline MSD-P & 0.0295 & 1.0000 & & & & & & & & \\
\hline ESD-P & 0.2145 & 0.1156 & 1.0000 & & & & & & & \\
\hline INCOME & -0.1252 & -0.2847 & -0.0239 & 1.0000 & & & & & & \\
\hline MCD & -0.1284 & 0.0987 & -0.0296 & -0.0140 & 1.0000 & & & & & \\
\hline TASTE & 0.0499 & -0.0355 & -0.0611 & 0.0554 & 0.0450 & 1.0000 & & & & \\
\hline SUB-P & -0.1873 & -0.3987 & -0.0722 & 0.0916 & -0.1339 & 0.0039 & 1.0000 & & & \\
\hline QSEED & 0.0239 & -0.0391 & 0.1112 & 0.0343 & -0.1339 & 0.0958 & -0.0671 & 1.0000 & & \\
\hline TABOO & 0.2782 & 0.0059 & 0.0452 & 0.0185 & -0.2091 & 0.0894 & -0.2173 & 0.2359 & 1.0000 & \\
\hline COM-P & -0.0570 & -0.0179 & -0.1293 & 0.3989 & 0.0726 & 0.0253 & -0.0908 & -0.0247 & -0.1377 & 1.0000 \\
\hline
\end{tabular}

Eigen-values: $($ sum $=10$, average value $=1$

\begin{tabular}{|c|c|c|c|c|c|c|c|c|c|c|}
\hline & D-P & MSD-P & ESD-P & $\mathrm{MCD}$ & Q-SEED & SUB-P & COM-P & TASTE & TABOO & INCOME \\
\hline Eigen-value & 1.8263 & 1.5168 & 1.3502 & 1.0560 & 0.9540 & 0.9450 & 0.7715 & 0.6662 & 0.4853 & 0.4288 \\
\hline Difference & 0.309 & 0.167 & 0.294 & 0.102 & 0.009 & 0.173 & 0.105 & 0.181 & 0.056 & - \\
\hline Proportion & 0.183 & 0.152 & 0.135 & 0.106 & 0.095 & 0.094 & 0.077 & 0.067 & 0.049 & 0.043 \\
\hline Cum. Value & 1.8263 & 3.3431 & 4.6934 & 5.7493 & 6.7032 & 7.6482 & 8.4120 & 9.0859 & 9.5712 & 10.000 \\
\hline Cumulative & 0.183 & 0.334 & 0.469 & 0.575 & 0.670 & 0.765 & 0.842 & 0.909 & 0.957 & 1.000 \\
\hline
\end{tabular}

\begin{tabular}{lrrrrrrrrrrr}
\hline & & & \multicolumn{1}{c}{ Eigen-vectors (loadings): } & & \\
\hline & PC 1 & PC 2 & PC 3 & PC 4 & PC 5 & PC 6 & PC 7 & PC 8 & PC 9 & PC 10 \\
D-P & 0.4182 & 0.1996 & 0.0673 & -0.2032 & 0.0366 & 0.6184 & -0.0307 & 0.4790 & 0.0967 & 0.3405 \\
MSD-P & 0.3661 & -0.4694 & 0.1973 & 0.0196 & -0.1008 & -0.2063 & 0.4188 & -0.1981 & 0.4468 & 0.3733 \\
ESD-P & 0.3041 & 0.0506 & -0.0451 & -0.5234 & 0.6797 & -0.0659 & 0.1262 & -0.2529 & -0.0207 & -0.2871 \\
MCD & -0.1174 & -0.4623 & 0.2255 & 0.1939 & 0.4365 & 0.0686 & -0.6382 & 0.1133 & 0.2610 & 0.0238 \\
QSEED & 0.1954 & 0.3893 & 0.1308 & 0.1624 & 0.2032 & -0.6900 & -0.0535 & 0.4690 & 0.0362 & 0.1591 \\
SUB-P & -0.4067 & 0.2366 & -0.4960 & -0.0087 & 0.1782 & 0.0537 & 0.1450 & 0.0516 & 0.6836 & 0.0834 \\
COM-P & -0.2991 & 0.0124 & 0.6196 & -0.2249 & -0.1171 & 0.0502 & 0.2694 & 0.3126 & 0.2673 & -0.4669 \\
TASTE & 0.0103 & 0.1868 & 0.2078 & 0.6969 & 0.4087 & 0.2884 & 0.3929 & -0.1408 & -0.0941 & -0.0546 \\
TABOO & 0.3952 & 0.4127 & 0.1447 & 0.1466 & -0.2730 & 0.0371 & -0.3720 & -0.3998 & 0.4125 & -0.2946 \\
INCOME & -0.3681 & 0.3326 & 0.4388 & -0.2501 & 0.0880 & 0.0024 & -0.1065 & -0.3930 & -0.0590 & 0.5672 \\
\hline
\end{tabular}

$\mathbf{V}^{*} \mathrm{D}-\mathrm{P}$ is initial demand price of ogbono, MSD-P is Mid-season demand price, ESD-P is End-of-season price, MCD is distance between market and consumption centre, QSEED is quality of seed, SUB-P is presence of okra as substitute, COM-P is presence of complementary commodity 
Table 04 shows the estimates of the parameters in ogbono demand regression and their associated t-ratios after a principal component analysis. The results showed an $\mathrm{R}^{2}$ of 0.751 and an adjusted $\mathrm{R}^{2}$ of 0.748 . The $\mathrm{R}^{2}$ value implies that $75.10 \%$ of the total variation in the quantity of ogbono demanded by the consumers in the study area is explained by the identified determinant of the item in the area. The results also showed that, of the determinant of the demand for ogbono, only the initial demand price, mid-season demand price, end-of-season price, price of substitute, distance between market and consumption centre, and the quality of seed were significant and at 5\% level of significance. While the beta coefficient of initial demand price was -0.510 , those of mid-season demand price, endof-season demand price, distance between market and consumption centre and price of substitute were respectively $-0.320,-0.223$,
-0.249 and -0.932 . These imply that, while a unit increase in the distance between market and consumption centre would be expected to decrease the quantity demanded of ogbono by consumers in the area by 0.249 in standard deviation unit for a one standard-deviation, N1.00 increase in the initial demand price, mid-season demand price and end-of-season price would be expected to respectively decrease the quantity demanded of ogbono by $0.510,0.320$ and 0.223 ceteris paribus, in standard unit for a one standard-deviation. The 0.932 coefficient of the price of substitute commodities implied the difference, between when there are available cheap substitute commodities and when there are not, in the expected decrease in quantity of ogbono demanded by the consumers in the study area, in standard deviation unit for a one standarddeviation.

Table 04: Estimates of the Parameters in the Irvingia kernel (Ogbono) Demand Regression and their associated t-value

\begin{tabular}{|c|c|c|c|}
\hline Variable & Parameters & $\begin{array}{l}\text { Beta weight Coefficient Before } \\
\text { Principal Component Analysis }\end{array}$ & $\begin{array}{l}\text { Beta weight Parameter After } \\
\text { Principal Component Analysis }\end{array}$ \\
\hline Constant & & $\begin{array}{l}5.602 * * \\
(2.075)\end{array}$ & $\begin{array}{l}4.511 * * \\
(2.182)\end{array}$ \\
\hline Initial demand price of ogbono & & $\begin{array}{l}-0.001 \\
(-0.653)\end{array}$ & $\begin{array}{l}-0.510 * * \\
(-3.041)\end{array}$ \\
\hline Mid-season demand price & & $\begin{array}{l}-0.001 \\
(-0.530)\end{array}$ & $\begin{array}{l}-0.320 * * \\
(-2.549)\end{array}$ \\
\hline End-of-season price & & $\begin{array}{l}-0.002 * * \\
(-2.305)\end{array}$ & $\begin{array}{l}-0.223 * * \\
(-2.005)\end{array}$ \\
\hline $\begin{array}{l}\text { Distance between market and } \\
\text { consumption centre }\end{array}$ & & $\begin{array}{l}-0.248 \\
(-0.728)\end{array}$ & $\begin{array}{c}-0.249 * * \\
(-4.071)\end{array}$ \\
\hline Quality of seed & & $\begin{array}{c}0.904 \\
(1.279)\end{array}$ & $\begin{array}{l}0.621 \\
1.279\end{array}$ \\
\hline Price of okra as substitute & & $\begin{array}{c}-1.637 * * \\
(-2.121)\end{array}$ & $\begin{array}{c}-0.932 * * \\
(-2.121)\end{array}$ \\
\hline Price of complementary commodities & & $\begin{array}{c}0.619 \\
(0.723)\end{array}$ & $\begin{array}{l}0.610 \\
(0.723)\end{array}$ \\
\hline Taste & & $\begin{array}{l}1.305 * * \\
(2.729)\end{array}$ & \\
\hline Taboo & & $\begin{array}{c}0.050 \\
(0.109)\end{array}$ & \\
\hline Income & & $\begin{array}{c}2.210 \\
(0.918)\end{array}$ & \\
\hline Coefficient of determination & & 0.275 & 0.751 \\
\hline Adjusted coefficient of determination & Adj. & 0.208 & 0.748 \\
\hline
\end{tabular}

*significant at 5\% level of significance 
The Table 04 also shows the estimates of the supply equation parameters after a principal component analysis. The results showed that the three statistically significant explanatory variables account for 0.879 , representing $87.9 \%$, of the total variation in the quantity of ogbono supplied by the producers while the others account for only 0.121 . The results showed that the initial supply price of irvinga, mid-season supply price and end-of-season price, with respective coefficient of 2.19 , 0.93 and 0.57 , are the major determinants of the supply of ogbono in the study area. These imply that $\mathrm{N} 1.00$ increase in the initial supply price of ogbono, mid-season supply price and end-of-season supply price would be expected to respectively increase the quantity supplied by producer in the area by $2.19,0.93$ and 0.59 , ceteris paribus, in standard unit for a one standard-deviation.

\section{REFERENCES}

Abbiw, D. K. (1990) Useful Plant of Ghana: West African uses of wild and Cultivated Plants, Intermediate Technology Publications and the Royal Botanic Garden, Kew.

Afifi, A. A; May, S and Clark, V. A (2012) Practical Multivariate Analysis. 5th ed. Boca Raton, FL: CRC Press.

Ayuk, E. T; Duguma, B; Franzel, S; Kengue, J; Mollet, M; Tiki-Manga, T; and Zenkekeng, P (1999) Uses, Manangement and Economic Potential of Irvingia gabonensis in the Humid Lowlands of Cameron, Forest Ecology and Management, 113 (5): 36-42

Courville, T., and Thompson, B. (2001) Use of Structure Coefficients in Published Multiple Regression Articles: ßeta is not enough. Educational and Psychological Measurement, 61, 229-248.

Dercon, S and Krishnan, P (2000) Vulnerability, Seasonality and Poverty in Ethiopia, Journal of Development Studies, 36 (6):25-53

Falconer, J (1990) The Major Significance of Minor Forest Products: The Local Use and Value of Forests in the West African Humid Forest Zone, Community Forest Note 6 FAO Rome

Feldman, B. (2005) "Relative Importance and Value," unpublished manuscript (Version 1.1, March 19 2005).Available online at http://www.prismanalytics.com/docs/ RelativeImportance050319.pdf. 
Fickel, N. (2001) “Sequenzialregression: EineneodeskriptiveL"osung des Multikollinearit" atspro blemsmittelsstufenweisebereinigter und synchronisierter Variablen," Habilitationsschrift, Berline: University of Erlangen-Nuremberg.

Firth, D. (1998) "Relative Importance of Explanatory Variables," Conference on Statistical Issues in the Social Sciences, Stockholm, October 1998. Online at http://www.nuff.ox.ac. $u k /$ sociology/ alcd/ relimp.pdf .

Firth, D (2006) Relimp: Relative Contribution of Effects in a Regression Model. R package version 0.9-6.

Fox, J (2002) "Bootstrapping Regression Models." In "An R and S-PLUS Companion to Applied Regression: A Web Appendix to the Book.", Sage, Thousand Oaks, CA. UR http://CRAN.R-project.org/doc/contrib/Fox-Companion/appendix-bootstrapping.pdf.

Gromping, U. (2006) "Relative Importance for Linear Regression in R: The Package relaimpo," Journal of Statistical Software, 17, Issue 1. Available online at http://www.jstatsoft.org/

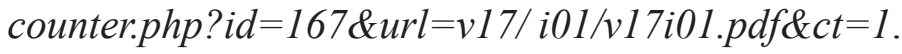

Hoyt, W. T., Leierer, S., \& Millington, M. (2006) Analysis and Interpretation of Findings using Multiple Regression Techniques. Rehabilitation Counseling Bulletin, 49, 223-233.

Jackson, J. E (2003) A User's Guide to Principal Components. New York: Wiley.

Jolliffe, I. T (2002) Principal Component Analysis. 2nd ed. New York: Springer.

Johnson, J. W. and Lebreton, J. M. (2004) "History and Use of Relative Importance Indices in Organizational Research," Organizational Research Methods, 7, 238-257.

Kruskal,W., and Majors, R. (1989) "Concepts of Relative Importance in Recent Scientific Literature," The American Statistician, 43, 2-6.

Lapido, D. O and Boland, D. J (1994) Trade in Irvingia Kernels: In D. O. Lapido and D. J. Boland (eds), Proceedings of the International Workshop on Irvingia in West Africa. International Center for Research in Agronomy (icraf), Nairobi, Kenya

Leaky, R; Schreckenberg, K and Techoundjeu, Z (2003) The Participatory Domestication of Indigenous Fruit, International Forestry Review, 5 (2): 38-47

Mbosso, M. F. P. C (1999) Opportunities et Constraints Socio-economiquesLiesa 1 Culture des arbresFruitiesLocauxdans les Basses TerresHumides du Cameroon: Dacreyodes Edulis et Irvingiagabonensis, Memorie de fin d'etudes present pour l'obstention du diploma d' IngenieurAgonome, Universite du Dechang, Pp 111

Nimon, K., Gavrilova, M., and Roberts, J. K. (2010) Regression Results in Human Resource Development Research: Are we reporting enough? In C. Graham \& K. Dirani (Eds.), Proceedings of the Human Resource Development 2010 International Conference (pp. 803-812), Knoxville, TN: AHRD. 
Pratt, J. W. (1987) Dividing the Indivisible: using Simple Symmetry to Partition Variance Explained. In T.Pukkila and S. Puntanen (eds.), Proceedings of the Second International Conference in Statistics (pp 245-260). Tampere, Finland: University of Tampere.

Rabe-Hesketh, S and Everitt, B. S (2007) A Handbook of Statistical Analyses Using Stata. $4^{\text {th }}$ ed. Boca Raton, FL: Chapman \& Hall/CRC.

Rencher, A. C and Christensen, W. F (2012) Methods of Multivariate Analysis. 3rd ed. Hoboken, NJ: Wiley.

Thomas, D. R. Zhu, P. and Decady Y (2007) Point estimates and confidence intervals for variable importance in multiple linear regression. Journal of Educational and Behavioral Statistics, 32, 61-91.

Van Belle, G.; Fisher, L. D; Heagerty, P. J and Lumley, T. S (2004) Biostatistics: A Methodology for the Health Sciences. 2nd ed. New York: Wiley.

Walsh C, Mac Nally R (2005) Their Part: Hierarchical Partitioning. R package version 1.0-1

Zientek, L. R., Capraro, M. M., and Capraro, R. M. (2008) Reporting Practices in Quantitative Teacher Education Research: One look at the evidence cited in the AERA panel report. Educational Researcher, 34, 208-216. doi: 10.3102/0013189X08319762 